\title{
Assessment of Barangay Nutrition Program Implementation in Selected Municipalities in Ifugao, Bulacan and Siquijor: Community Partners' Perspectives
}

\author{
Ma. Socorro Endrina- Ignacio \\ Department of Nutrition, College of Public Health, University of the Philippines Manila
}

\begin{abstract}
Objectives. To characterize the implementation of BNAP in selected barangays in the chosen municipalities in Ifugao, Bulacan and Siquijor. It hopes to a) identify nutrition strategies that worked and did not work based on the perception of the nutrition program beneficiaries and b) identify factors that may have contributed to the accomplishment and nonaccomplishment of nutrition program objectives.

Methods. One hundred thirty seven (137) community partners (i.e.mothers with children less than 5 years old) consented to be the respondents in a focus group discussion. The FGD Guide was used to elicit: a) awareness of barangay nutrition activities focused on their experiences during participation, strong and weak points on how the activities are conducted, b) perception of nutrition activities, perceived benefits derived from participating in nutrition activities and extent of involvement, and c) suggestions to improve and sustain the implementation of barangay nutrition program and their committed role to improve its implementation. Appreciative inquiry approach was used to elicit respondents' satisfaction on the effect of nutrition program on children's health.
\end{abstract}

Results. In general, the respondents across all study barangays, regardless of the prevalence of undernutrition, are aware of the nutrition activities being implemented in their respective barangays and claimed that they have participated in various nutrition interventions implemented by the barangay nutrition scholars (BNS). Some of the reported and observed "positive" effects of nutrition activities in the study barangays include: children's weight improved, learned to eat vegetables and appetite improved-no longer a picky eater, and mothers learned more nutritious recipes to serve their family. Some respondents however, think otherwise, because their children are still

Corresponding author: Ma. Socorro E. Ignacio, RND, DrPH

Department of Nutrition

College of Public Health

University of the Philippines Manila

625 Pedro Gil Street, Ermita, Manila 1000 Philippines

Telephone: +6325255858

Email: chorie_phil@yahoo.com underweight, became more sickly after receiving vaccination and have not observed any improvement in the nutritional status of the children in their barangay.

Conclusion. Variations in the BNAP implementation were observed in this study. The nutrition program components that distinguish the low and high prevalence municipalities were evident based on the respondents' reported activities. The variety of nutrition activities were dependent on the adequacy of logistical support and commitment of the BNS in pursuing what is indicated in the BNAP as crucial to improve nutrition program management. However, unique program elements as experienced by some coming from low or high prevalence barangays cannot be used to explain the effect of the program in terms of nutritional status of the preschool children as reflected in the annual OPT and hence cannot be isolated. The inputs (i.e. barangay logistical support) and processes (i.e. nutrition activities) considered critical in program management are similarly found in both low and high prevalence provinces and municipalities. Across all study areas, respondents find the nutrition advice given by the BNS helpful in the care of their children. It can be concluded that the planned nutrition activities in the BNAP anchored on PPAN are known and participated in by the respondents. The nutrition activities were aligned and consistent with what is reflected in the BNAP, are aligned with the MNAP and to some extent to PPAN.

Key Words: PPAN, BNAP, Barangay Nutrition Program Assessment, Localization of PPAN

\section{Introduction}

The Philippine Plan of Action for Nutrition (PPAN) is the country's blueprint for planning nutrition interventions at the local levels. Since 1974, the National Nutrition Council (NNC) has formulated eight (8) PPAN. ${ }^{1}$ These plans have been cascaded to the municipalities to direct/guide the implementation of barangay nutrition programs for almost 40 years now. Unfortunately, the nutritional situation of the country has not improved significantly based on Food and Nutrition National Survey. As shown in Table 1, although the prevalence of underweight among 0-60 months decreased from $27.4 \%$ in 1990 to $20.2 \%$ in 2011, the annual average reduction of 0.34 percentage points for the past 21 years is not fast enough to achieve one of the targets of the Millennium Development Goal 1 (MDG1) which is to halve 
the proportion of underweight children (from 27.4 percent in 1990 to 13.7 percent by 2015) 2,3

Hunger incidence in the country remains a serious concern. Official government statistics and data from hunger surveys show an increasing trend in hunger incidence among Filipino households. The National Statistical Coordination Board (NSCB) reported that the percentage of subsistence poor in the country increased to 14.6 percent in 2006 from 13.5 percent in 2003. ${ }^{4}$

Table 1. Trends in malnutrition prevalence among children 0-60 months based on WHO-CGS: Philippines, 1990-2011

\begin{tabular}{ccccc}
\hline Year & Underweight & Underheight & Wasting & $\begin{array}{c}\text { Overweight for } \\
\text { Height }\end{array}$ \\
\hline 1990 & 27.4 & 44.7 & 6.2 & 1 \\
1993 & 26.6 & 38.9 & 7.7 & 1.5 \\
1996 & 23.6 & 39.9 & 6.2 & 1.6 \\
1998 & 25.5 & 38.9 & 6.8 & 1.4 \\
2001 & 23 & 35.9 & 6.8 & 2 \\
2003 & 20.7 & 33.8 & 6 & 2.4 \\
2005 & 20.2 & 33.1 & 5.8 & 2.5 \\
2008 & 20.7 & 32.4 & 6.9 & 3.3 \\
2011 & 20.2 & 33.6 & 7.3 & 4.3 \\
\hline
\end{tabular}

PPAN 2011-2016 is the country's $8^{\text {th }}$ national plan for nutrition. Like the earlier national nutrition plans, it aims to reduce the prevalence of malnutrition in the country. The goal of PPAN 2011-2016 is to contribute to improving the quality of the human resource base of the country and to reducing child and maternal mortality. It is also envisioned to contribute to the achievement of the UN Millennium Development Goals (MDGs) as well as poverty reduction. The key strategies and priorities for action of PPAN 20112016 are a "mix of services that are specific to the form of malnutrition and those that would impact on all forms of undernutrition". ${ }^{5}$ PPAN strategies are cascaded to the different municipalities to serve as guide in formulating the Municipal Nutrition Action Plan (MNAP). The Barangay Nutrition Action Plan (BNAP) nutrition strategies are anchored on the MNAP. These include: a) promotion of breastfeeding, b) provision of complementary feeding program for young children less than 5 years old, c) conduct of nutrition education and promotion, d) integration of nutrition services in ante-natal care particularly among high risk pregnant women, e) integrated package of nutrition services in the school and alternative school system, f) provision of micronutrient supplements to reduce the prevalence of vitamin A deficiency, iodine deficiency disorders and iron deficiency anemia among infants 6-11 months old, one-year -olds, pregnant and lactating women, g) promotion of backyard gardening through distribution of vegetable seedlings and $\mathrm{h}$ ) promotion of healthy lifestyle to prevent a further increase in the levels of overweight and obese children and adults.

Local government units (LGUs) play a crucial role in implementing PPAN 2011-2016 throughout the country through MNAP and BNAP implementation. The MNAP and BNAP planning and implementation are facilitated by the Municipal Nutrition Committee (MNC) and the Barangay Nutrition Committee (BNC), respectively. The said committees replicate the inter-agency composition of the NNC to serve as the coordinating structure for nutrition action as the sub-national level. Under the directive of the Department of Interior and Local Government (DILG) the local chief executives i.e. mayors and barangay chairpersons are mandated to provide leadership in nutrition planning, implementation, monitoring and evaluation of nutrition programs at the local level. They are expected to provide logistical support and designate Barangay Nutrition Scholars (BNSs) dedicated to oversee implementation of nutrition programs at the municipal and barangay levels. ${ }^{6}$

This commissioned study aims to assess and describe how nutrition programs are implemented at the barangay level. The funding agency wants a document that will serve as a guide for the various local stakeholders to address the problem of malnutrition, poverty and inequity in their respective areas. Through this study, local nutrition planners will be guided by the expressed sentiments and perceptions of the mothers with pre-school age children (nutrition program beneficiaries) referred to as community partners in this study.

\section{Objectives}

To describe holistically the implementation of nutrition program in the chosen barangays in selected municipalities in Ifugao, Bulacan and Siquijor, this qualitative study gathered information from the program beneficiaries/community partners coming from barangays with high and low prevalence of undernutrition. More specifically, the study aims to:

1. Identify nutrition strategies that worked and did not work based on the assessment of the nutrition program beneficiaries;

2. Identify factors that may have contributed to the accomplishment and non-accomplishment of local nutrition program objectives.

\section{Methods}

This qualitative study using focus groups discussions (FGD) and appreciative inquiry approach was carried out in June-August 2013. One hundred thirty seven (137) community partners/mothers, with age range of 24-37 years old, with children less than 5 years old consented to participate in the FGD. The FGD guide consisted of questions that elicited: a) awareness of barangay nutrition activities focused on their experiences during participation, strong and weak points on how the activities are conducted, b) perception of nutrition activities, perceived benefits derived from participating in nutrition activities and extent of involvement, and c) suggestions to improve and sustain 
the implementation of barangay nutrition program and their committed role to improve its implementation. Appreciative inquiry approach was used to elicit respondents' satisfaction on the effect of nutrition program on children's health. This process made use of very happy, happy, neutral, sad and very sad emoticons. These qualitative data collection methods were used in describing program implementation, studying process, studying participation, getting program participants' views or opinions about program's impact, and identifying program strengths and weaknesses. In order for the assessment to be organizationally anchored, consultation meetings with the technical staff of the Department of Health- National Nutrition Council (DOH-NNC) Secretariat and MNAOs of the covered municipalities were also conducted prior to the barangay data collection. This process was useful in describing the profile of the study areas. The project documents obtained from the same offices that were reviewed to understand the conditions around the BNAP implementation included, Annual Accomplishment Reports, $7,8,9$ minutes of meetings of the BNC, and budgetary allocation from the barangay and OPT 2010-2013 results of the provinces, municipalities and the selected barangays were obtained from the MNAOs and BNSs. The basis for the selection of study sites and participants is shown in Table 2. The study was done in three provinces selected on the basis of the severity and magnitude of underweight among 0-71 months using the results of the FNRI 2011 Updating Survey ${ }^{10}$ following the classification of the worldwide prevalence ranges of WHO in 1995. Prevalence is considered low if the rate is <10; medium (10-19); high (20-29) and very high $(>=30)$. From each province, two municipalities with the lowest and highest prevalence of underweight for age among 0-71 months old based on the municipal OPT results for 2012 were selected.11,12,13 From each municipality, two barangays categorized as high prevalence and low prevalence based on the same 2012 OPT results were also selected. Classification of high and low prevalence municipality/barangay is relative to the provincial and municipal ranking of the OPT results. ${ }^{11,12,13}$ In certain cases when it is not recommended to go to the municipality/barangay with the highest and lowest ranking because of distance or security concerns, the next highest or lowest municipality/barangay was selected. The Provincial Nutrition Action Officer (PNAO) and the Municipal Action Officer (MNAO) were consulted in the selection of municipalities and barangays.The collected data were consolidated, summarized and analysed. Themes arising from the FGDs were grouped and cross-checked with field notes and references/documents reviewed. Comparisons/contrasts of the perceptions and opinions obtained from the respondents were tabulated between and among municipalities and barangay using the prevalence of underweight as the unit of analysis.
Table 2. Basis for the selection of study barangays

\begin{tabular}{ll}
\hline \multicolumn{1}{c}{ Study Site } & \multicolumn{1}{c}{ Basis for Selection } \\
\hline Province & WHO Classification \\
- Low, medium, high prevalence & Low $:<10$ \\
of underweight 0-60 months & Medium: 10-20 \\
based on FNRI 2011 updating & High: 21-30 \\
survey & Very High: $>30$ \\
$\begin{array}{l}\text { Municipality } \\
\begin{array}{l}\text { - High and low prevalence } \\
\text { Barangay }\end{array} \\
\text { - High and low prevalence }\end{array}$ & Based on 2011 Operation Timbang \\
\hline
\end{tabular}

\section{Results}

\section{Profile of Study sites}

The study was conducted in Ifugao, Bulacan and Siquijor.The prevalence of underweight children in Ifugao was estimated to be $7.2 \%$ in the year 2011, which was the lowest among the Philippine provinces while Siquijor had the highest prevalence of $46.0 \% .^{10}$ Prevalence rate of Bulacan for the same year is $13.3 \%$ (Table 3 ). In addition, Ifugao was selected to represent a community with indigenous people (IP). From 2009 to 2011, Bulacan has been awarded the Consistent Regional Outstanding Winner (CROWN) as judged by the National Nutrition Council's Monitoring \& Evaluation for Local Level Planning and Implementation (MELLPI). ${ }^{14}$ The CROWN award is given to a municipality, city or province that has been adjudged by the interagency regional evaluation team as outstanding in the region in the implementation of its nutrition action plan for three consecutive years. ${ }^{15}$ In 2012, Bulacan has been candidate for the Nutrition Honor Award (NHA). The NHA is given to CROWN awardees that have consistently shown outstanding performance in efforts for nutrition improvement for three consecutive years. The performances of these provinces were monitored by regional nutrition evaluation team for three years and by the national evaluation team. Ifugao on the other hand, received its first CROWN award in 2010, was able to maintain it in 2011 and for 2012, it is vying for its $2^{\text {nd }}$ year maintenance CROWN award in 2013. Siquijor on the other hand, never won any award (Table 4).The prevalence of underweight children of the municipalities and barangays selected for the study is shown in Tables 5 and 6. Prior to data collection, based on the documents review and interview of MNAOs, BNSs' supervisors, the covered municipalities except in Siquijor have functional municipal nutrition committees (MNC) that monitor the implementation of barangay nutrition programs. The Barangay Nutrition Scholars (BNSs) are responsible for the implementation of nutrition program at the barangay level. The MNAO guides the BNS in mobilizing local partners to make the Barangay Nutrition Committees (BNC) functional. The status of MNC functionality is shown in Table 7. 
Table 3. Prevalence of underweight (0-60 months) in the selected provinces

\begin{tabular}{lcl}
\hline \multicolumn{1}{c}{ Province } & Prevalence $^{{ }^{1}}$ & Classification $^{2}$ \\
\hline Ifugao & 7.2 & Low \\
Bulacan & 13.3 & Medium \\
Siquijor & 46.0 & Very high \\
National prevalence average & \multicolumn{2}{c}{20.2} \\
Prevalence Range & & \multicolumn{2}{c}{$7.2-46$} \\
\hline
\end{tabular}

${ }^{1}$ Based on 2011 updating survey of FNRI

${ }^{2}$ Based on WHO Classification

Table 4. MELLPI standing of the selected provinces

\begin{tabular}{cllc}
\hline Year & \multicolumn{1}{c}{ Ifugao } & \multicolumn{1}{c}{ Bulacan } & Siquijor \\
\hline 2009 & None & CROWN Year 1 & None \\
2010 & CROWN Year 1 & $\begin{array}{l}\text { CROWN First Year } \\
\text { Maintenance }\end{array}$ & None \\
& & CROWN Second & None \\
2011 & CROWN First Year & Year Maintenance & \\
& Maintenance & Vying for Nutrition & None \\
2012 & Vying for CROWN & Honor Award & \\
& Second Year & & \\
\hline Source: & NNC MELLPI Report (unpublished) &
\end{tabular}

Table 5. Prevalence of underweight children (0-71 months) in the selected municipalities

\begin{tabular}{lccc}
\hline $\begin{array}{c}\text { Muncipality } \\
\text { Classification }\end{array}$ & IFUGAO & BULACAN & SIQUIJOR \\
\hline Low & Lagawe (2.96; & Sta. Maria(1.40) & E. Villanueva (2.13) \\
High & Kiangan (3.65 & DRT(8.63) & San Juan (8.46) \\
Average prevalence & 3.76 & 2.52 & 6.26 \\
Prevalence Range & $2.04-6.32$ & $0.06-8.63$ & $2.13-8.46$ \\
\hline${ }^{1}$ Based on 2012 OPT results (relative to other municipalities \\
in the same province) \\
Note: Figures in parenthesis are the prevalence rates
\end{tabular}

Table 6. Prevalence of underweight children (0-71 months) in the selected barangays

\begin{tabular}{|c|c|c|c|c|c|}
\hline \multirow{2}{*}{ Province } & \multirow{2}{*}{ Municipality } & \multicolumn{2}{|c|}{ Barangay } & \multirow{2}{*}{$\begin{array}{c}\text { Prevalence } \\
\text { Range }\end{array}$} & \multirow{2}{*}{$\begin{array}{c}\text { Average } \\
\text { Prevalence }\end{array}$} \\
\hline & & Low & High & & \\
\hline \multirow[t]{2}{*}{ Ifugao } & $\begin{array}{l}\text { Lagawe } \\
\text { (Low) }\end{array}$ & $\begin{array}{l}\text { Olilicon } \\
\text { (0) }\end{array}$ & $\begin{array}{l}\text { Boliwong } \\
\text { (3) }\end{array}$ & $0.0-12.5$ & 2.75 \\
\hline & $\begin{array}{l}\text { Kiangan } \\
\text { (High) }\end{array}$ & $\begin{array}{l}\text { Tuplac } \\
(2.75)\end{array}$ & $\begin{array}{c}\text { Baguinge } \\
\quad(5.09)\end{array}$ & $0.0-7.34$ & 3.59 \\
\hline \multirow[t]{2}{*}{ Bulacan } & $\begin{array}{l}\text { Sta. Maria } \\
\quad(\text { low })\end{array}$ & $\begin{array}{c}\text { Buenavista } \\
(.59)\end{array}$ & $\begin{array}{c}\text { Sta. Cruz } \\
(.83)\end{array}$ & $0.0-3.7$ & 1.13 \\
\hline & $\begin{array}{l}\text { DRT } \\
\text { (High) }\end{array}$ & $\begin{array}{c}\text { Camachile } \\
\text { (4.91) }\end{array}$ & $\begin{array}{c}\text { PulongSampaloc } \\
(5.74)\end{array}$ & $\begin{array}{c}\text { Not } \\
\text { available }\end{array}$ & $\begin{array}{c}\text { Not } \\
\text { available }\end{array}$ \\
\hline \multirow[t]{2}{*}{ Siquijor } & $\begin{array}{l}\text { E. Villanueva } \\
\text { (Low) }\end{array}$ & $\begin{array}{l}\text { Libo } \\
(2.15)\end{array}$ & $\begin{array}{c}\text { Poblacion } \\
(4.54)\end{array}$ & $0.0-9.0$ & 3 \\
\hline & $\begin{array}{l}\text { San Juan } \\
\text { (High) }\end{array}$ & $\begin{array}{r}\text { Maite } \\
(6.49)\end{array}$ & $\begin{array}{c}\text { Cansayang } \\
(9.43)\end{array}$ & $1.37-12.7$ & 6.99 \\
\hline
\end{tabular}

${ }^{1}$ Based on 2012 OPT results (relative to other barangays in the same municipality)

Note: Figures in parenthesis is the prevalence rate
Table 7. Perceived functionality of the Municipal Nutrition Committees

\begin{tabular}{lll}
\hline \multicolumn{1}{c}{ Perception } & \multicolumn{1}{c}{ Area } & \multicolumn{1}{c}{ Classification } \\
\hline \multirow{3}{*}{ Functional } & Sta. Maria, Bulacan & Low prevalence \\
& Lagawe, Ifugao & Low prevalence \\
& DRT, Bulacan & High prevalence \\
& Kiangan, Ifugao & High prevalence \\
\multirow{2}{*}{ Not functional } & San Juan, Siquijor & High prevalence \\
& E. Villanueva, Siquijor & Low prevalence \\
\hline
\end{tabular}

\section{Community Partners' Awareness of Nutrition Activities}

In both low and high prevalence barangays, community partners are aware of almost similar nutrition activities being implemented in their area as shown in Table 8 . Feeding program topped the list of reported nutrition activities in the barangay.Two types of feeding programs exist in the area: Day Care Center (DCC) feeding and community-based feeding which include food distribution to the severely underweight children identified during the annual OPT. In the DCC feeding, respondents recalled their involvement in the preparation of ingredients for the day's recipe, cooking, distribution of food to the children, cleaning of the cooking area and washing the cooking implements. The BNS was mentioned to have assisted during the feeding session by monitoring the weight of the enrolled children. This action is appreciated by the respondents as they are able to see the effect of the feeding program on their children's weight. Some were aware that ingredients should be supported/provided by the barangay but this is not happening which is why in most of the barangays, regardless of the prevalence of undernutrition, mothers contribute ingredients from their own household just to make the recipes palatable and acceptable to the children. The annual OPT and the monthly weighing of severely underweight children were also mentioned by majority of the respondents. Food supplementation program was mentioned by the mothers in both high and low undernutrition prevalence barangays. Under this program, undernourished children are given food packs containing milk, noodles, nutripack, biscuits or a combination of any of these food items. The food ration is done weekly but majoriy of the respondents cannot specify for how many weeks it lasted. In barangays with high undernutrition prevalence, mothers remembered the occasional center-based feeding sponsored by various organizations but this activity is irregular, usually done once a year-during nutrition month celebration. Others mentioned seed distribution, "Pabasa sa Nutrisyon"session, cooking demonstration, health related activities, i.e. Vitamin A supplementation, deworming, immunization, livelihood training (i.e hair cutting and rug making) and backyard gardening. It is to be noted that in both low and high undernutrition prevalence barangays, the mentioned activities are similar. Activities vary in terms of frequency and duration depending on availability of funds provided by the sponsoring agencies. The respondents from 
the low prevalence barangays reported more frequent nutrition related activities compared to the high prevalence barangays.

Table 8. Awareness of Barangay Nutrition Activities in low and high undernutrition prevalence barangays

\begin{tabular}{ll}
\hline Low Prevalence Barangays & High Prevalence Barangays \\
\hline - & Feeding \\
- & Distribution of food commodities \\
& (e.g. milk, biscuit, grocery items) \\
- & Operation Timbang (house-to-house weighing) \\
- Vegetable gardening and seed distribution \\
- Vitamin A supplementation \\
- Immorming \\
- PabasasaNutrisyon \\
- Breastfeeding promotion \\
- Family planning lecture \\
- Cooking lessons \\
- Prenatal care \\
\hline
\end{tabular}

\section{Memorable and Beneficial Nutrition Activities}

Memorable (unforgettable) and beneficial nutrition activities (with observed positive effects) derived from participating in various nutrition activities are shown in Table 9. Respondents attributed their memorable experiences from the additional knowledge gained and the observed benefits on their children's well-being as a result of participating in barangay nutrition activities. Specifically, respondents find the annual OPT and monthly weighing memorable because their children enjoyed the swing-type scale and the outreach services that went with it, i.e. vitamin supplementation, family planning and nutrition counselling. They expressed appreciation of the BNS's commitment and dedication in tracking the weight of their children.The DCC feeding was mentioned as the most memorable activity by majority of the mothers in both low and high undernutrition prevalence barangays from all the provinces covered.This is considered so because they learned new cooking techniques, gained new friends while on-duty at the day care center and like their children, they are also able to eat what they cook when there are left over food. Some mentioned that there are occasions when they can also bring home left-over food and unused condiments. Establishing backyard garden is also memorable because it provides easy access to vegetables which they can add to their family meals. This was mentioned by respondents from both low and high prevalence barangays in Ifugao and Bulacan.

\section{Observed Effects of Nutrition Activities on Children's Health}

The respondents shared some of the observed effects of nutrition activities among children in their barangay. Responses obtained were categorized into positive and negative effects. In both low and high undernutrition prevalence barangays, the commonly observed positive effects of the nutrition activities include increased weight, improvement in health and improved appetite (Table 10). On the other hand, a few respondents shared that there were no observable effects of the nutrition activities in their barangay.

"Wala pa akong nakita na magandang epekto" (No observable positive change ).

"Marami pa ring payat na bata" (There are still underweight children in the community).

Table 9. Memorable nutrition related activities participated in by the community partners

\begin{tabular}{|c|c|c|c|}
\hline Memorable activities & Reasons & Barangay & Classification \\
\hline OPT house to house & $\begin{array}{l}\text { - Weight of children tracked, BNS } \\
\text { concerned about health of their } \\
\text { children }\end{array}$ & $\begin{array}{l}\text { Olilicon, Lagawe } \\
\text { Tuplac, Kiangan } \\
\text { Camachile, DRT } \\
\text { Baguinge, Kiangan }\end{array}$ & $\begin{array}{l}\text { Low prevalence } \\
\text { Low prevalence } \\
\text { Low prevalence } \\
\text { High prevalence }\end{array}$ \\
\hline Feeding at DCC & $\begin{array}{l}\text { - Learned new cooking techniques } \\
\text { - Gained new friends } \\
\text { - Able to eat left over } \\
\text { - Brought home left over ingredients }\end{array}$ & $\begin{array}{l}\text { Libo, E. Villanueva } \\
\text { Camachile, DRT } \\
\text { Maite, San Juan } \\
\text { Sta. Cruz, Sta. Maria } \\
\text { Poblacion, E. Villanueva } \\
\text { Baguinge, Kiangan } \\
\text { Cansayang, San Juan }\end{array}$ & $\begin{array}{l}\text { Low prevalence } \\
\text { Low prevalence } \\
\text { Low prevalence } \\
\text { High prevalence } \\
\text { High prevalence } \\
\text { High prevalence } \\
\text { High prevalence }\end{array}$ \\
\hline $\begin{array}{l}\text { Backyard gardening, Family Development } \\
\text { Sessions (4Ps), distribution of milk to } \\
\text { malnourished children, livelihood }\end{array}$ & $\begin{array}{l}\text { - Reduced vegetable expense, access } \\
\text { to fresh produce, extra income } \\
\text { from hair-cutting and soap making }\end{array}$ & $\begin{array}{l}\text { Olilicon, Lagawe } \\
\text { Buenavista, Sta. Maria } \\
\text { Tuplac, Kiangan } \\
\text { Sta Cruz, Sta. Maria } \\
\text { Baguinge, Kiangan }\end{array}$ & $\begin{array}{l}\text { Low prevalence } \\
\text { Low prevalence } \\
\text { Low prevalence } \\
\text { High prevalence } \\
\text { High prevalence }\end{array}$ \\
\hline
\end{tabular}


Table 10. Observed positive effects of nutrition activities on children's health

\begin{tabular}{|c|c|c|}
\hline Positive effects & Barangay & Classification \\
\hline Children gained weight & $\begin{array}{l}\text { Buenavista, Sta. Maria } \\
\text { Libo, E. Villanueva } \\
\text { Tuplac, Kiangan } \\
\text { Camachile, DRT } \\
\text { Boliwong, Lagawe } \\
\text { Sta. Cruz, Sta. Maria } \\
\text { PulongSampalok, DRT } \\
\text { Cansayang, San Juan }\end{array}$ & $\begin{array}{l}\text { Low prevalence } \\
\text { Low prevalence } \\
\text { Low prevalence } \\
\text { Low prevalence } \\
\text { High prevalence } \\
\text { High prevalence } \\
\text { High prevalence } \\
\text { High prevalence }\end{array}$ \\
\hline $\begin{array}{l}\text { Weight improved but still } \\
\text { underweight }\end{array}$ & Buenavista, Sta. Maria & Low prevalence \\
\hline $\begin{array}{l}\text { Children learned to eat } \\
\text { vegetables and a variety of } \\
\text { foods everyday }\end{array}$ & $\begin{array}{l}\text { Libo, E. Villanueva } \\
\text { Tuplac, Kiangan } \\
\text { Camachile, DRT } \\
\text { Maite, San Juan } \\
\text { Boliwong, Lagawe } \\
\text { Baguinge, Kiangan } \\
\text { Cansayang, San Juan }\end{array}$ & $\begin{array}{l}\text { Low prevalence } \\
\text { Low prevalence } \\
\text { Low prevalence } \\
\text { Low prevalence } \\
\text { High prevalence } \\
\text { High prevalence } \\
\text { High prevalence }\end{array}$ \\
\hline $\begin{array}{l}\text { Children's appetite } \\
\text { improved }\end{array}$ & $\begin{array}{l}\text { Olilicon, Lagawe } \\
\text { Libo, E. Villanueva } \\
\text { Tuplac, Kiangan } \\
\text { Maite, San Juan } \\
\text { Boliwong, Lagawe } \\
\text { Sta. Cruz, Sta. Maria } \\
\text { PulongSampalok, DRT } \\
\text { Cansayang, San Juan }\end{array}$ & $\begin{array}{l}\text { Low prevalence } \\
\text { Low prevalence } \\
\text { Low prevalence } \\
\text { Low prevalence } \\
\text { High prevalence } \\
\text { High prevalence } \\
\text { High prevalence } \\
\text { High prevalence }\end{array}$ \\
\hline
\end{tabular}

\section{Satisfaction on the effects of nutrition program on children's health}

Using the emoticons, respondents satisfaction on the effects of nutrition programs on children's health was gathered. Majority appreciated the benefits of nutrition activities undertaken in their barangay, albeit limited. They chose the very happy emoticon in relation to their attendance to mother's classes because they learned meal preparation techniques that they were able to apply at home. Half of the respondents chose the very happy emoticon to reflect their opinion about their barangay's nutrition activities for the following reasons: nutritional needs of their children are met; other people (i.e. BNSs) are also looking after the health and nutrition welfare of their children. The reasons given by the respondents are tabulated in Table11. Those who chose the happy emoticon also mentioned improvement in child's weight, noticeable increase in appetite, performance in school, improved protection against sickness due to vitamin supplementation and immunization as the main reasons for their satisfaction (Table 12). Others expressed satisfaction on the cooking lessons they attended because they were able to apply their learned skills to help their children gain weight. They added, "the cooking lessons taught them several vegetable recipes that their children loved to eat."
Table 11. Reasons why respondents are very satisfied with the nutrition activities implemented in their barangay

\begin{tabular}{|c|c|c|}
\hline $\begin{array}{l}\text { Reasons for choosing } \\
\text { VERY HAPPY emoticon }\end{array}$ & Barangay & Classification \\
\hline $\begin{array}{l}\text { Obtained knowledge on } \\
\text { how to care for children } \\
\text { properly }\end{array}$ & Olilicon, Lagawe & Low prevalence \\
\hline - Child's weight improved & Olilicon, Lagawe & Low prevalence \\
\hline $\begin{array}{l}\text { - Her child's weight } \\
\text { improved }\end{array}$ & Maite, San Juan & Low prevalence \\
\hline $\begin{array}{l}\text { - Other people are looking } \\
\text { after her child's health }\end{array}$ & Buenavista, Sta. Maria & Low prevalence \\
\hline $\begin{array}{l}\text { - Regular attendance to } \\
\text { nutrition activities }\end{array}$ & PulongSampalok, DRT & High prevalence \\
\hline $\begin{array}{l}\text { - Her child eats vegetables } \\
\text { and is healthy }\end{array}$ & Cansayang, San Juan & High prevalence \\
\hline
\end{tabular}

Table 12. Reasons why respondents are satisfied with the nutrition activities implemented in their barangay

\begin{tabular}{|c|c|c|}
\hline $\begin{array}{l}\text { Reasons for choosing } \\
\text { HAPPY emoticon }\end{array}$ & Barangay & Classification \\
\hline - Improved child's weight & Olilicon, Lagawe & Low prevalence \\
\hline $\begin{array}{l}\text { - Child is not sickly } \\
\text { - Improved child's weight } \\
\text { and appetite }\end{array}$ & Tuplac, Kiangan & Low prevalence \\
\hline $\begin{array}{l}\text { - Children are physically } \\
\text { better }\end{array}$ & Buenavista, Sta. Maria & Low prevalence \\
\hline $\begin{array}{l}\text { - Improved child's weight } \\
\text { - Improved children's } \\
\text { performance }\end{array}$ & Libo, E. Villanueva & Low prevalence \\
\hline $\begin{array}{l}\text { - Child is not so sickly } \\
\text { anymore } \\
\text { - Child eats vegetables }\end{array}$ & Maite, San Juan & Low prevalence \\
\hline $\begin{array}{l}\text { - There is support for their } \\
\text { children } \\
\text { - Her child eats vegetables }\end{array}$ & Camachile, DRT & Low prevalence \\
\hline $\begin{array}{l}\text { - Child is not so sickly } \\
\text { - Child is given vitamin } \\
\text { supplements but refuses } \\
\text { to swallow his food }\end{array}$ & Boliwong, Lagawe & High prevalence \\
\hline $\begin{array}{l}\text { - Improved child's weight } \\
\text { and appetite } \\
\text { - Child is not sickly }\end{array}$ & Baguinge, Kiangan & High prevalence \\
\hline $\begin{array}{l}\text { Obtained knowledge on } \\
\text { how to prepare nutritious } \\
\text { meals }\end{array}$ & PulongSampalok, DRT & High prevalence \\
\hline - Improved child's weight & Sta. Cruz, Sta. Maria & High prevalence \\
\hline $\begin{array}{l}\text { There are free food } \\
\text { commodities, vitamin } \\
\text { supplements and } \\
\text { medicines }\end{array}$ & Sta. Cruz, Sta Maria & High prevalence \\
\hline $\begin{array}{l}\text { - Improved child's weight } \\
\text { and appetite }\end{array}$ & Poblacion, E. Villanueva & High prevalence \\
\hline $\begin{array}{l}\text { - Children are healthy due } \\
\text { to obtained knowledge } \\
\text { about nutrition }\end{array}$ & Cansayang, San Juan & High prevalence \\
\hline
\end{tabular}


On the other hand, few were not so happy and chose neutral emoticon with their assessment on the effect of nutrition activities on the children's health. Table 13 shows the reasons for feeling such. The general sentiments of those who chose the neutral emoticon stems from their perception that something is still lacking in nutrition activities. In high undernutrition prevalence barangays, one mother said she is expecting to receive continuous services, i.e. vitamin supplementation for children and she noticed that her child is still thin and sickly after attending the feeding program. One mother shared that her child became sicklier after vaccination. In a barangay in Siquijor, majority of mothers were neutral because of the quality of nutrition activities implemented in their barangay. They remember an instance where the children were given spoiled milk. They further added that they will be satisfied only when the underweight children have increased their weight. They feel that more still needs to be done and hope that more help will reach their barangay. Some mothers also mentioned the need to increase financial support to nutrition program in their barangay. One mother expressed that government's support is not felt in the barangay. Some respondents were also not happy with how nutrition program is managed in their barangay. One respondent said"Kuan, murag wala may epekto pod. Kaning mga programa wala man epekto sa mga tawo pod."(I think the programs here do not have an effect with the people). Concerning food supplies, some mothers shared that they observed uneven allocation of the supplies for feeding program. One parent commented that the nutrition program is selective and not all children are given equal opportunity to participate in the said programs.

Table 13. Reasons why respondents are "neutral" about the nutrition activities implemented in their barangay

\begin{tabular}{|c|c|c|}
\hline Reasons for NEUTRAL feelings & Barangay & Classification \\
\hline $\begin{array}{l}\text { Not familiar with the } \\
\text { programs since their family } \\
\text { just moved to the barangay }\end{array}$ & $\begin{array}{l}\text { Buenavista, Sta. } \\
\text { Maria }\end{array}$ & Low prevalence \\
\hline $\begin{array}{l}\text { - "It seems there is no observable } \\
\text { change" }\end{array}$ & $\begin{array}{l}\text { Baguinge, } \\
\text { Kiangan }\end{array}$ & High prevalence \\
\hline $\begin{array}{l}\text { - Child is not sickly but longs } \\
\text { for increased appetite }\end{array}$ & $\begin{array}{l}\text { Boliwong, } \\
\text { Lagawe }\end{array}$ & High prevalence \\
\hline $\begin{array}{l}\text { "I think the programs here do } \\
\text { not have an effect with the } \\
\text { people" }\end{array}$ & $\begin{array}{l}\text { Poblacion, E. } \\
\text { Villanueva }\end{array}$ & High prevalence \\
\hline $\begin{array}{l}\text { - "I rarely attend barangay } \\
\text { nutrition activities" }\end{array}$ & $\begin{array}{l}\text { PulongSampalok, } \\
\text { DRT }\end{array}$ & High prevalence \\
\hline
\end{tabular}

\section{Perceived Barriers to Participation in Nutrition Activities}

Barriers to participation in nutrition activities were also explored. Regardless of the barangay's prevalence of undernutrition, the most commonly mentioned barriers had to do with schedule of the activity and conflict with domestic and economic activities of the respondents. Specific barriers mentioned include: a) nobody is left to take care of their children; b) time set for nutrition activities usually conflict with household chores and work in the field;c) nutrition seminars are scheduled on school days, mothers have to prioritize children needs than attendance to said seminar; d) some mothers with small business can attend seminar if scheduled on weekend and no classes, where other family members are available to take care of small kids, and e)husbands cannot attend nutrition activities if scheduled on weekdays

Suggestions to overcome hindrances in implementing nutrition programs in the barangay

To overcome hindrances in implementing nutrition program in the barangay, the respondents want to see more coordinated nutrition activities i.e. feeding, vitamin supplementation and livelihood activities with sustained funding and support from barangay officials, regular implementation of nutrition program and avoid "politicking". Timely dissemination of information on nutrition activities is also recommended by the mothers to ensure their active participation in nutrition activities. One said that, this will enable her to get a surrogate caregiver for her children that will allow her to attend the nutrition seminar. Stricter implementation of nutrition program by the BNS and regular budgetary support from the barangay were suggested by most of the respondents.

\section{Suggestions to Improve Community Satisfaction on Barangay Nutrition Program}

To convert the community partners' happy feeling to very happy feeling with regard to nutrition program implementation in their barangay, majority said they want to participate in more activities with adequate logistical support from the barangay. The responses are shown in Table 14.

\section{Discussion}

This qualitative assessment of the BNAP implementation from the community partner's perspectives revealed sentiments and opinions that should serve as a guide to various stakeholders in nutrition on how to improve and enhance barangay nutrition program planning and management.

\section{Community Partners' Awareness of Nutrition Activities}

Majority of the respondents from barangays with low and high undernutrition prevalence were aware of the nutrition activities that are implemented in their barangays. The mentioned activities are consistent with what is reflected in the BNAP, anchored on the MNAP. They have good recollection of the program's purpose and what they are supposed to receive as they participate in the programs. 
Table 14. Suggestions to Improve Community Partners' Satisfaction on the Barangay Nutrition Program.

\begin{tabular}{|c|c|c|}
\hline Suggestions & Barangay & Classification \\
\hline $\begin{array}{l}\text { Continuous } \\
\text { implementation of } \\
\text { feeding projects }\end{array}$ & $\begin{array}{l}\text { Libo, E. Villanueva } \\
\text { Tuplac, Kiangan } \\
\text { Camachile, DRT } \\
\text { Boliwong, Lagawe } \\
\text { Sta. Cruz, Sta. Maria } \\
\text { Poblacion, E. Villanueva }\end{array}$ & $\begin{array}{l}\text { Low prevalence } \\
\text { Low prevalence } \\
\text { Low prevalence } \\
\text { High prevalence } \\
\text { High prevalence } \\
\text { High prevalence }\end{array}$ \\
\hline $\begin{array}{l}\text { More activities where } \\
\text { mothers and children can } \\
\text { participate to improve } \\
\text { their children's health } \\
\text { and nutrition }\end{array}$ & $\begin{array}{l}\text { Libo, E. Villanueva } \\
\text { Sta. Cruz, Sta. Maria } \\
\text { Poblacion, E. Villanueva } \\
\text { Cansayang, San Juan }\end{array}$ & $\begin{array}{l}\text { Low prevalence } \\
\text { High prevalence } \\
\text { High prevalence } \\
\text { High prevalence }\end{array}$ \\
\hline $\begin{array}{l}\text { Additional livelihood } \\
\text { projects (e.g. } \\
\text { establishment of } \\
\text { cooperatives, } \\
\text { microfinance }\end{array}$ & $\begin{array}{l}\text { Camachile, DRT } \\
\text { Sta. Cruz, Sta. Maria } \\
\text { Poblacion, E. Villanueva } \\
\text { Baguinge, Kiangan } \\
\text { PulongSampalok, DRT } \\
\text { Cansayang, San Juan }\end{array}$ & $\begin{array}{l}\text { Low prevalence } \\
\text { High prevalence } \\
\text { High prevalence } \\
\text { High prevalence } \\
\text { High prevalence } \\
\text { High prevalence }\end{array}$ \\
\hline $\begin{array}{l}\text { Increased distribution of } \\
\text { food commodities (e.g. } \\
\text { milk and cookies) and } \\
\text { vitamin supplements } \\
\text { from government }\end{array}$ & Sta. Cruz, Sta. Maria & High prevalence \\
\hline $\begin{array}{l}\text { Continuous distribution } \\
\text { of vitamin supplements }\end{array}$ & $\begin{array}{l}\text { Olilicon, Lagawe } \\
\text { Libo, E. Villanueva } \\
\text { Tuplac, Kiangan } \\
\text { Boliwong, Lagawe } \\
\text { Baguinge, Kiangan } \\
\text { Cansayang, San Juan }\end{array}$ & $\begin{array}{l}\text { Low prevalence } \\
\text { Low prevalence } \\
\text { Low prevalence } \\
\text { High prevalence } \\
\text { High prevalence } \\
\text { High prevalence }\end{array}$ \\
\hline $\begin{array}{l}\text { Distribution of a variety } \\
\text { of seeds, not just string } \\
\text { beans }\end{array}$ & Olilicon, Lagawe & Low prevalence \\
\hline $\begin{array}{l}\text { Increased supplies at the } \\
\text { Health Center }\end{array}$ & Cansayang, San Juan & High prevalence \\
\hline $\begin{array}{l}\text { Increased budget nor } \\
\text { nutrition activities }\end{array}$ & Cansayang, San Juan & High prevalence \\
\hline $\begin{array}{l}\text { Community members } \\
\text { want to see their children } \\
\text { playful, happy, not sickly } \\
\text { and chubby }\end{array}$ & Baguinge, Kiangan & High prevalence \\
\hline $\begin{array}{l}\text { Additional seminar on } \\
\text { child ( } 9-15 \text { years) rearing }\end{array}$ & Olilicon, Lagawe & Low prevalence \\
\hline
\end{tabular}

\section{Memorable and Beneficial Effects of Nutrition Activities}

The study was able to elicit insights on how the program beneficiaries feel about nutrition program activities being implemented in their respective barangays as indicated in Tables 9-12. On one hand, it successfully highlighted nutrition activities that are perceived to be "working" as seen mainly in terms of improvement of children's health and nutrional status and "achieving" the purpose for what they were designed for, which is to improve the nutritional status of the children measured in terms of weight from the respondents' point of view. The activities that the respondents cannot forget (or memorable) are those which they considered to have brought about good result to their children's health-as measured by their weight gain, improved body resistance, changes in physical wellbeing, better social interaction with other children, improved appetite and learned eating habit of vegetable consumption.
Satisfaction on the effects of nutrition program on children's health

Across all study sites, regardless of the prevalence of undernutrition, the respondents were satisfied with the effect of nutrition program on their childrens' overall wellbeing. The degree of satisfaction, however, varies depending on the length of the respondents' exposure and result of their experience in participating in various nutrition activities in their barangay. They are very happy with how the BNS, coordinator of barangay nutrition program is doing her job of annual weighing, monthly weighing of children who are underweight, assisting in feeding program, distribution of vitamins, delivery of health services, i.e. immunization and pre-natal care, home visit and distribution of vegetable seedlings.

\section{Perceived Barriers to Participation in Nutrition Activities}

If some respondents gave positive feedback on barangay nutrition program implementation, Table 12, shows the respondents' sentiments on why some nutrition activities seem not to realize its intended purpose because they did not see not much improvement in their children's weight. Few articulated that this could be due to: irregular and short duration of community feeding program by private agencies, irregular food assistance and vitamin distrbution initiatives, unfair enlistment of children in the community-based feeding program and inadequate supply of ingredients.

\section{Suggestions to overcome hindrances in implementing} nutrition programs in the barangay

Respondents gave their suggestions to overcome the perceived barriers that prevented them from participating in nutrition activities in their barangay. These include: early dissemination of the schedule nutrition classes/seminars so they can arrange for a relative to watch over their children or take over the management of small business and scheduling nutrition activities on weekends to enable their husband's participation and involvement.

\section{Suggestions to Improve Community Satisfaction on Barangay Nutrition Program}

There is no doubt that the respondents are willing to attend and participate in barangay nutrition activities. However, they are expecting a better system of disseminating information on the schedule of nutrition activities, timing, and more logistical support from the barangay to ensure continuity of program that will sustain their interest. More specifically, they want to learn more from nutrition and cooking classes, benefit from uninterrupted supply of vitamins and longer duration of the community feeding program to improve the nutritional status of their chuildren. They also want to have more 
livelihood programs that could help them augment family income without leaving their home.

\section{Conclusions and Recommendations}

Variations in the BNAP implementation were observed in this study. The nutrition program components that distinguish the low and high prevalence municipalities were evident based on the respondents' reported activities. The variety of nutrition activities were dependent on the adequacy of logistical support and commitment of the BNS in pursuing what is indicated in the BNAP as crucial to improve nutrition program management. However, unique program elements as experienced by some coming from low or high prevalence barangays cannot be used to explain the effect of the program in terms of nutritional status of the preschool children as reflected in the annual OPT and hence cannot be isolated. The inputs (i.e. barangay logistical support) and processes (i.e. nutrition activities) considered critical in program management are similarly found in both low and high prevalence provinces and municipalities. Across all study areas, respondents find the nutrition advice given by the BNS helpful in the care of their children. It can be concluded that the planned nutrition activities in the BNAP anchored on PPAN are known and participated in by the respondents. The nutrition activities were aligned and consistent with what is reflected in the BNAP, are aligned with the MNAP and to some extent to PPAN. The respondents appreciated some of the intended outcomes of the nutrition programs and they recognize and appreciate the efforts of the BNSs as primarily responsible for the delivery of nutrition interventions in the barangay. The BNSs enjoy high credibility and people's confidence amidst the articulated socio-political issues around BNAP implementation. The collective formulation of BNAP and resource sharing of the BNC member agencies which are essential indicators of functionality of local nutrition committees spells good nutrition programming that was remembered as beneficial by community partners. The study exposed the following areas to improve the BNAP implementation: logistical support from the barangay, timely dissemination of announcement on nutrition activities, conditions that would elicit the commitment of community to improve barangay nutrition program implementation at the barangay level. As a way forward, there is a need to scale up this study to cover a more representative cross-section of provinces and municipalities and to be able to generate recommendations for policy improvement and reduce gap in program implementation. Quantitative study may also be conducted to complement the assessment findings.

\begin{abstract}
Acknowledgments
The author gratefully acknlowledges the National Anti-Poverty Commission (NAPC) for the technical guidance, United Nations Development Ptogramme (UNDP) for funding support, National Nutrition Council (NNC) Secretariat, PNAO, MNAO and BNSs' for their support and insights during the pre-field and field data collection, NAPC TWG and NNC Technical Committee for technical review and clearance of the report, Dr. Milagros Querubin for her valuable technical inputs and NAPC secretariat for their administrative support.
\end{abstract}

\section{References}

1. Food and Nutrition Research Institute. Philippine Nutrition Facts and Figures 2005. FNRI-DOST,2007, pp.14-15.

2. Food and Nutrition Research Institute. Philippine Nutrition Facts and Figures 2011. FNRI-DOST, 2012,pp.48-49.

3. National Economic and Development Authority, Status report on the millenium development goals using CBMS data [Online]. 2010 [cited 2012 June]. Available from http:// www.neda.gov.ph/econreports_dbs/ MDGs/4thProgress2010/PROVINCIAl_Reports/Siquijor/pdf.

4. National Statistics Office, The 2010 census of population and housing reveals the Philippine population at 92.34 Million" [Online]. 2012 [cited 2012 June]. Available from http://www.census.gov.ph/content/2010census-population-and-housing-reveals-philippine-population-9234million.

5. National Nutrition Council. Philippine Plan of Action for Nutrition, Abridged version. NNC Secretariat, April 13, 2013. Unpublished.

6. Department of Interior and Local Government, Memorandum circular no.2012-89 [Online]. 2011 [cited 2012 July]. Available from www.dilg.gov.ph.

7. Annual Accomplishment Reports 2010,2011, 2012, Ifugao (MNAO file). Unpublished.

8. Annual Accomplishment Reports 2010, 2011,2012, Bulacan (MNAO file). Unpublished.

9. Annual Accomplishment Reports 2010,2011,2012, Siquijor (PNAO file). Unpublished.

10. Food and Nutrition Research Institute. Philippine Nutrition Facts and Figures 2011. FNRI-DOST, 2012 Table 2.1 pp 3-5.

11. OPT Report, Ifugao, 2012 (BNS file). Unpublished.

12. OPT Report, Bulacan, 2012 (BNS file). Unpublished.

13. OPT Report, Siquijor, 2012 (BNS file). Unpublished.

14. National Nutrition Council. Guidelines on the Monitoring and Evaluation of Implementation of the Philippine Plan of Action for Nutrition at Provincial, City and Municipalities. NNC Secretariat, 2006.

15. National Nutrition Council. Awarding Ceremony Program. Philippine International Convention Center, November 9, 2012. 